\title{
SITUACIÓN SOCIOECONÓMICA DE LA PRODUCCIÓN Y COMERCIALIZACIÓN DE TOTOMOXTLE EN EL ESTADO DE PUEBLA, MÉXICO
}

\section{SOCIOECONOMIC SITUATION OF TOTOMOXTLE PRODUCTION AND COMMERCIALIZATION IN THE STATE OF PUEBLA, MEXICO}

\author{
Martha del Carmen Flores-Rosales ${ }^{1}$, J. Arahón Hernández-Guzmán*1, Pedro Antonio López ${ }^{1}$, Abel Gil-Muñoz ${ }^{1}$, \\ Filemón Parra-Inzunza ${ }^{1}$, Rene Hortelano-Santa Rosa ${ }^{2}$
}

\begin{abstract}
${ }^{1}$ Colegio de Postgraduados-Campus Puebla. Estrategias para el Desarrollo Agrícola Regional. Boulevard Forjadores de Puebla Núm. 205, Santiago Momoxpan, Municipio de San Pedro Cholula, 72760. Puebla, México. (flores-martha@hotmail.com, arahon@colpos.mx; palopez@ colpos.mx; gila@colpos.mx; fparra@colpos.mx). ${ }^{2}$ Instituto Nacional de Investigaciones Forestales, Agrícolas y Pecuarias. Campo Experimental Valle de México. Km 13.5, Carretera Los Reyes-Texcoco, 56250, Coatlinchán, Texcoco, Estado de México. (hortelano.rene@inifap. gob.mx).
\end{abstract}

\section{RESUMEN}

En México, el aprovechamiento integral del maíz complementa ingresos de la unidad de producción. Esta investigación se realizó en el estado de Puebla, México, para documentar aspectos sociales y económicos vinculados a la produclción, acopio y comercialización de totomoxtle en las regiones de Puebla, Serdán y Tehuacán. En 2011 se aplicaron 33 cuestionarios a comercializadores de totomoxtle en los principales mercados del estado. Otro instrumento se aplicó a 47 productores de totomoxtle en las localidades que suministraron el mayor volumen de totomoxtle a esos mercados. Con la información obtenida se calcularon estadísticos descriptivos, y se realizaron análisis de varianza, componentes principales, conglomerados y correspondencia. Se encontró que el mayor porcentaje del totomoxtle que se comercializa en los principales mercados provino de localidades relativamente cercanas a ellos. El 100\% de los productores que comercializaron totomoxtle utilizaron semilla de poblaciones nativas de maíz seleccionada del ciclo anterior. Hubo diferencias entre productores de totomoxtle, atribuibles a variables económicas (vinculadas a la ganancia derivada de la venta de productos del maíz), productivas, y a otras asociadas con el tiempo dedicado a la producción y aprovechamiento del totomoxtle. La mayoría de los productores (59.6\%) tuvo una relación beneficio-costo menor a uno cuándo sólo aprovecharon el grano del maíz; este beneficio se incrementó entre 8.3 y $31.2 \%$ al agregar el aprovechamiento del totomoxtle. Productores de Altepexi (región Tehuacán) obtuvieron los mayores volúmenes de grano y totomoxtle, y los más altos beneficios por la venta de ambos productos. El $11 \%$ de los productores

* Autor responsable $*$ Author for correspondence.

Recibido: enero, 2018. Aprobado: diciembre, 2018.

Publicado como ARTÍCULO en ASyD 18: 85-104. 2021.

\section{ABSTRACT}

In Mexico, the integral use of maize complements the income of production units. This study was carried out in the state of Puebla, Mexico, to document social and economic aspects linked to the production, collection and commercialization of totomoxtle in the regions of Puebla, Serdán and Tehuacán. In 2011, 33 questionnaires were applied to totomoxtle sellers in the main state markets. Another instrument was applied to 47 totomoxtle producers in the localities that supply the highest volume of totomoxtle to these markets. With the information obtained, descriptive statistics were calculated and variance, principal components, cluster and correspondence analyses were carried out. It was found that the highest percentage of totomoxtle that is sold in the main markets came from relatively nearby localities. Of the producers who sold totomoxtle, 100\% used seed from native maize populations selected from the previous cycle. There were differences between totomoxtle producers attributable to economic variables (linked to the profit derived from the sale of maize products), productive variables, and other variables associated to the time devoted to totomoxtle production and use. Most of the producers (59.6\%) had a benefit-cost relationship lower than one whey they only used maize grain; this benefit increased between 8.3 and $31.2 \%$ when adding the use of totomoxtle. Producers from Altepexi (Tehuacán region) obtained the highest volumes of grain and totomoxtle, and the highest benefits from the sale of both products. Of the producers, $11 \%$ considered that totomoxtle production is more relevant than grain production, while $76 \%$ of them conferred the same importance to grain and to totomoxtle production.

Key words: maize, totomoxtle, added value. 
consideró que la producción de totomoxtle es más relevante que la producción de grano, mientras que $76 \%$ de ellos confirió la misma importancia a la producción de grano y de totomoxtle.

Palabras clave: maíz, totomoxtle, valor agregado.

\section{INTRODUCCIÓN}

$\mathrm{E}$ l cultivo del maíz contribuye al sustento de millones de agricultores y se encuentra incluido entre los tres cereales más importantes a nivel mundial (Hellin et al., 2010). En México, la importancia del cultivo se explica por su contribución a la producción económica nacional, por la fuerte conexión con la cultura mexicana y, sobre todo, por el papel clave que desempeña en el sustento de las familias en el medio rural (Sweeney et al., 2013). En el ciclo agrícola primavera-Verano 2016, el maíz para grano ocupó el primer lugar nacional en cuanto a superficie sembrada en condiciones de temporal, con 5616632 ha y una producción de 8212702 t. Para el mismo ciclo y modalidad de siembra, el estado de Puebla ocupó el tercer lugar nacional, superado sólo por Chiapas y Jalisco; en ese año, en Puebla se estableció con maíz una superficie de 494532 ha, con una producción de 711080 t (SIAP, 2016).

En el país existen tanto agricultores orientados a la producción comercial de maíz como aquéllos dedicados exclusivamente al autoconsumo o a éste y una cierta proporción de venta en pequeño en mercados locales. Los primeros, quienes comúnmente emplean variedades híbridas, se ubican en la zona norte del país; los otros grupos se distribuyen mayormente en la zona centro y suroeste, y emplean poblaciones locales o nativas (Keleman et al., 2009), que son las que mejor responden tanto a su entorno ambiental como a sus necesidades de consumo. Debido a que los agricultores que cultivan poblaciones nativas no siempre generan ganancias suficientes con la venta del grano (Sweeney et al., 2013), recurren a la venta de productos especiales de maíz, los cuales llegan a tener precios más altos que el de grano. Cabe mencionar que algunos mercados especializados son más accesibles para agricultores que producen pequeños volúmenes de grano (Hellin et al., 2013).

Entre las especializaciones que benefician a la economía campesina y familiar se encuentra la producción de maíz azul y la de maíz harinoso de grano grande para hacer pozole (Hellin et al., 2013); la

\section{INTRODUCTION}

$\mathrm{M}$ aize cultivation contributes to the sustenance of millions of farmers and is included among the three most important cereals worldwide (Hellin et al., 2010). In Mexico, the importance of the crop is explained by its contribution to the national economic production, due to the strong connection with Mexican culture, and above all, because of the key role that it plays in the sustenance of the families in the rural environment (Sweeney et al., 2013). In the 2016 spring-summer agricultural cycle, maize for grain occupied the first place domestically in terms of surface sown under rainfed conditions, with 5616632 ha and a production of 8212702 t. For the same cycle and modality of sowing, the state of Puebla occupied the third place nationwide, exceeded only by Chiapas and Jalisco; in that year, maize in Puebla was established with a surface of 494532 ha, with a production of $711080 \mathrm{t}$ (SIAP, 2016).

In the country there are both farmers directed at commercial maize production and those devoted exclusively to auto-consumption, or to the latter and a certain proportion for small-scale sale in local markets. The first, who commonly use hybrid varieties, are located in the northern zone of the country; the other groups are distributed mostly in the central and southwestern zone, and they use local or native populations (Keleman et al., 2009), which are the ones that best respond both to their environment and to their consumption needs. Because farmers who cultivate native populations do not always earn sufficient profit by selling grain (Sweeney et al., 2013), they resort to the sale of special maize products, which manage to attain higher prices than the grain. It should be mentioned that some specialized markets are more accessible to farmers who produce small volumes of grain (Hellin et al., 2013).

Among the specialties that benefit the peasant and family economy, we can mention: production of blue maize and floury maize of large grain to make pozole (Hellin et al., 2013); the production and commercialization of corn on the cob which is left in order to reach commercial maturity for grain production, when the harvest is delayed (Ortiz-Torres et al., 2013); and huitlacoche collection (Ustilago 
producción y comercialización de elote, que en caso de que se retarde la cosecha se deja a que alcance la madurez comercial para la producción de grano (Ortiz-Torres et al., 2013) y la recolección de huitlacoche (Ustilago maydis), un hongo que se considera un manjar en México (Hellin et al., 2013).

Otro producto que se genera a partir del maíz y del que existe demanda en mercados nacionales e internacionales es el totomoxtle (hojas de maíz) o brácteas que cubren a la mazorca. La importancia del totomoxtle radica entre otros aspectos en que aporta fotosintatos para el desarrollo de los granos en maíz (Kang et al., 1986), pues la tasa fotosintética máxima del totomoxtle expresada en base a clorofila es similar a la de las hojas del maíz (Penguelly et al., 2011); protege a la mazorca contra daños de insectos en campo (Demissie et al., 2008); es útil para la preparación de tamales y elaboración de artesanías (Long y Villarreal, 1998); su fibra es similar en calidad a la que producen el algodón y el lino, lo cual le confiere potencial para uso textil e industrial (Reddy y Yang, 2005a; 2005b), cualidad que se corroboró a través de la evaluación de las propiedades fisicoquímicas del totomoxtle, lo cual demostró su potencial para varias aplicaciones textiles (Jain et al., 2017); tiene potencial para utilizarse en materiales para construcción, muebles, artículos decorativos y otros campos, ya que a partir de fibras extraídas del totomoxtle se han aislado compuestos retardantes de flama (Lihua et al., 2017); y aun cuando los niveles de antocianinas en maíz morado varían en forma significativa entre las distintas partes de la planta, se encontró que hay regiones del totomoxtle en donde su contenido es elevado, por lo que un uso adicional del totomoxtle podría ser como fuente de antioxidantes (Chun-Ying et al., 2008), ya que posee además altos niveles de fenoles, flavonoides y cetosteroides totales, por lo que puede ser utilizado como candidato potencial para la prevención de enfermedades relacionadas con varios sub productos del metabolismo humano (Dong et al., 2014). Estos y otros usos del totomoxtle, podrían revalorizar la producción del maíz en México y el mundo.

Por otra parte, la comercialización del totomoxtle es una de las estrategias que emplean los agricultores para obtener un beneficio extra de la producción de maíz (Flores-Rosales et al., 2015), aunque también tiene impactos ecológicos negativos a escala local debido a los cambios en las prácticas de selección que realizan los productores, al favorecer a través de ellas maydis), a mushroom that is considered a delicacy in Mexico (Hellin et al., 2013).

Another product generated from maize and for which there is demand in national and international markets is "totomoxtle" or bracts that cover the ear (cornhusks). The importance of totomoxtle lies, among other aspects, in that it contributes photosynthates for the development of maize grains (Kang et al., 1986), since maximal photosynthetic rates are similar between the maize leaf and cornhusk when expressed on a chlorophyll basis (Penguelly et al., 2011); it protects the ear against damage from field insects (Demissie et al., 2008); it is useful in the preparation of tamales and to make handcrafts (Long and Villarreal, 1998); its fiber is similar in quality to the one produced by cotton and linen, conferring potential for textile and industrial use (Reddy and Yang, 2005a; 2005b), quality that was corroborated through the evaluation of the physicochemical properties of totomoxtle, which showed its potential for several textile applications (Jain et al., 2017); it has potential to be used in construction materials, furniture, decorative articles, and other fields, since flame-delaying compounds have been extracted from totomoxtle fibers (Lihua et al., 2017); and even though the levels of anthocyanins in purple maize vary significantly between different parts of the plant, it was found that there are regions of totomoxtle where their content is high, which is why an additional use of totomoxtle could be as a source of antioxidants (Chun-Ying et al., 2008), since it also has higher levels of phenols, flavonoids and total ketosteroids, so it can be used as potential candidate for the prevention of diseases related to many byproducts of human metabolism (Dong et al., 2014). These and other uses of totomoxtle could revalue maize production in Mexico and the world.

On the other hand, the commercialization of totomoxtle is one of the strategies that farmers use to obtain an extra benefit from maize production (Flores-Rosales et al., 2015), although it also has negative ecological impacts at the local scale due to changes in the selection practices performed by producers, when they favor maize populations that produce more totomoxtle than grain, which can lead to the loss of other populations, thus decreasing the genetic diversity of maize (King, 2007). In response to the existing demand for totomoxtle, some states of Mexico such as Nayarit (Rice, 2007), Jalisco, 
a poblaciones de maíz que producen más totomoxtle que grano, lo cual puede llevar a la pérdida de otras poblaciones, disminuyendo con esto la diversidad genética del maíz (King, 2007). En respuesta a la demanda que existe del totomoxtle, algunos estados de México como Nayarit (Rice, 2007), Jalisco, Colima, Michoacán, Oaxaca y Tamaulipas (Long y Villareal, 1998) y en la región Totonaca del estado de Veracruz (King, 2007), en donde ya existen centros de acopio de totomoxtle, se ha generado un esquema en el cual los agricultores, a través de la cosecha y venta del totomoxtle, se benefician del cultivo de poblaciones nativas de maíz, al mismo tiempo que obtienen ingresos extras para su familia.

En el estado de Puebla, Flores-Rosales et al. (2015) desarrollaron un estudio en tres regiones productoras de maíz, y demostraron la existencia de una amplia variación para características relacionadas con la calidad del totomoxtle. También concluyeron que las poblaciones nativas de maíz cultivadas en la región de Tehuacán son las que poseen las características más sobresalientes para el aprovechamiento del totomoxtle. A pesar del potencial para producción de totomoxtle presente en algunas regiones del estado de Puebla y de las evidencias de que se cuenta con una gran diversidad y riqueza genética de poblaciones nativas de maíz, existen pocos estudios sobre la importancia económica y social que tiene el totomoxtle en las regiones productoras más importantes de dicho cereal en la entidad. Entre estos estudios se encuentra el de Viveros-Flores et al. (2010) quienes reportaron que en el valle de Puebla, $72 \%$ de las unidades familiares aprovechan el totomoxtle, y que en esos casos, entre 70 y $100 \%$ de la producción obtenida es destinada a la venta. Dichos autores señalan que las unidades familiares que se dedican al aprovechamiento del totomoxtle se caracterizaron por tener las menores superficies destinadas a la siembra de maíz, presentar escasa actividad pecuaria, ser familias comparativamente más grandes que el promedio y contar con menores ingresos. Otras regiones donde se sabe que el aprovechamiento de totomoxtle es una práctica más generalizada entre los agricultores, son el trópico húmedo poblano y Tehuacán, aunque de estas últimas no existen reportes escritos.

Considerando que en el estado de Puebla existen evidencias documentadas y empíricas de que el aprovechamiento del totomoxtle de poblaciones nativas de maíz es una actividad relevante, se llevó a cabo la
Colima, Michoacán, Oaxaca and Tamaulipas (Long and Villareal, 1998), and in the Totonaca region of the state of Veracruz (King, 2007), where there are already totomoxtle collection centers, a scheme has been generated where farmers, through the harvest and sale of totomoxtle, benefit from the cultivation of native maize populations, at the same time that they obtain extra income for their family.

In the state of Puebla, Flores-Rosales et al. (2015) performed a study in three maize producing regions and they showed the existence of a broad variation for characteristics related to the quality of totomoxtle. They also concluded that the native maize populations grown in the Tehuacán region are the ones that have the most outstanding characteristics for the exploitation of totomoxtle. Despite the potential for totomoxtle production present in some regions of the state of Puebla and the evidence that there is great diversity and genetic wealth in native maize populations, there are few studies about the economic and social importance of totomoxtle in the most important producing regions of this cereal in the state. Among these studies is the one by Viveros-Flores et al. (2010), who reported that in the valley of Puebla, $72 \%$ of the family units use totomoxtle and that, in these cases, between 70 and $100 \%$ of the production obtained is destined for sale. These authors point out that the family units devoted to the use of totomoxtle are characterized by having the smallest surfaces destined to maize sowing, present scarce livestock production activity, are comparatively larger families than average, and have lower income. Other regions where it is known that the use of totomoxtle is a more generalized practice among farmers are the humid sub-tropical region and Tehuacán, although there are no written reports about these.

Considering that in the state of Puebla there is documented and empirical evidence that the use of totomoxtle from native maize populations is a relevant activity, this study was carried out with the following objectives: a) to identify the principal localities of origin for totomoxtle that is sold in the local and regional markets, documenting at the same time aspects linked to its process of collection and distribution; and b) to analyze social and economic aspects linked to farmers devoted to the production and use of totomoxtle, in three regions of the state of Puebla. The hypotheses suggested were that 
presente investigación con los objetivos de: a) identificar a las principales localidades de donde proviene el totomoxtle que se comercializa en los mercados locales y regionales, documentando a la vez aspectos ligados a su proceso de acopio y distribución; y b) analizar aspectos sociales y económicas vinculados a los agricultores dedicados a la producción y aprovechamiento de totomoxtle, en tres regiones del estado de Puebla. Se plantearon las hipótesis de que el totomoxtle se aprovecha principalmente en el ámbito lo$\mathrm{cal}$, de que su uso incrementa ingresos en la producción de maíz y de que existen similitudes socioeconómicas entre los agricultores que lo aprovechan.

\section{MATERIALES Y MÉTODOS}

\section{Área de estudio y tamaño de muestra}

La investigación se desarrolló en dos etapas. En la primera se condujo una encuesta en la cual se aplicaron 33 cuestionarios; seis de ellos en la central de abastos de Puebla, ubicada en la ciudad de Puebla, así como en mercados regionales de importancia en el estado, como los de Huejotzingo (nueve cuestionarios), Cholula (siete), Chalchicomula de Sesma (tres) y el "tianguis" La Purísima, del municipio de Tehuacán (ocho). No se determinó un tamaño de muestra previo, sino que en cada sitio se aplicó el instrumento sólo a comerciantes que entre los productos ofertaban el totomoxtle. Con los resultados se identificaron las principales localidades productoras y comercializadoras de totomoxtle, lo que permitió realizar la segunda etapa, que consistió en aplicar cuestionarios dirigidos a productores de totomoxtle, en las localidades de San Francisco Cuautlancingo, municipio de Chalchicomula de Sesma (región Serdán); Atzala y Calpan, del municipio de Calpan, y Tepatlaxco de Hidalgo, municipio del mismo nombre, todas estas de la región Puebla. Lo mismo se realizó en las localidades de San José Miahuatlán y Altepexi, pertenecientes a municipios del mismo nombre, en la región Tehuacán (Figura 1). Aplicando el muestreo no probabilístico conocido como "bola de nieve", se encuestó a un total de 47 productores, repartidos de la siguiente manera: seis en San Francisco Cuautlancingo, ocho en Atzala, ocho en Calpan, 15 en Tepetlaxco de Hidalgo, cinco en San José Miahuatlán y cinco en Altepexi. totomoxtle is used primarily in the local sphere, that its use increases income in maize production, and that there are socioeconomic similarities between the farmers that use it.

\section{MATERIALS AND METHODS}

\section{Study area and sample size}

The study was developed in two stages. In the first one, a survey was conducted where 33 questionnaires were applied; six of them in the wholesale food market in Puebla, located in the city of Puebla, as well as in regional markets that are important in the state, such as Huejotzingo (nine questionnaires), Cholula (seven), Chalchicomula de Sesma (three), and La Purísima tianguis in the municipality of Tehuacán (eight). A sample size was not determined previously, but rather in each site the instrument was applied only to sellers who offered totomoxtle

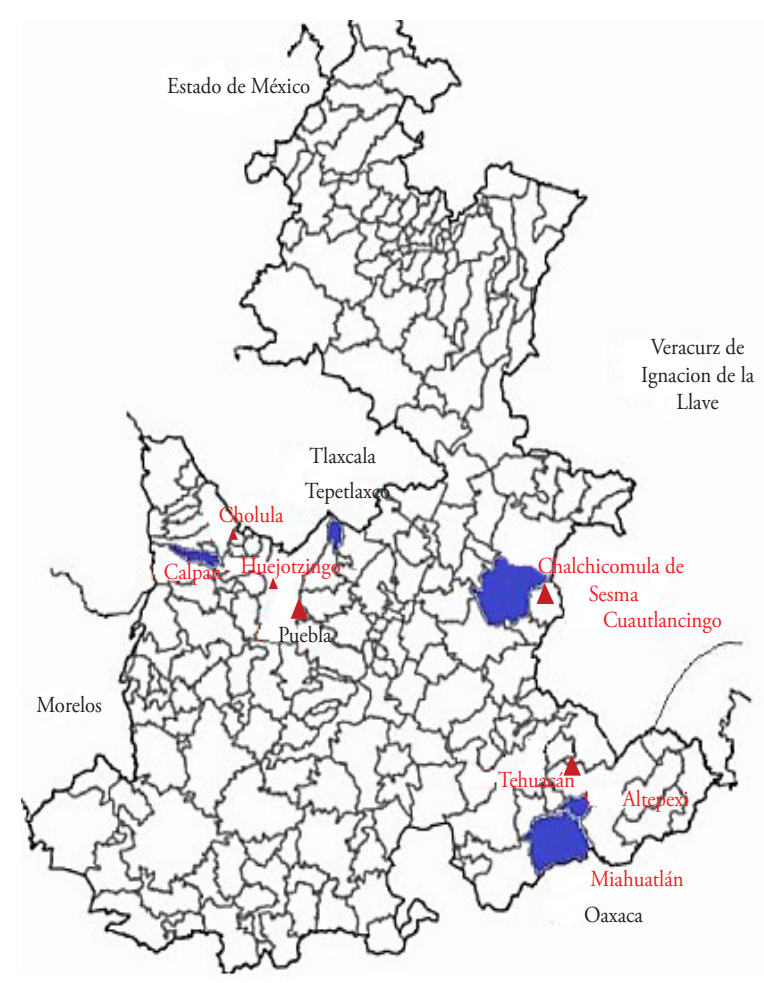

Figura 1. Ubicación de lugares donde se aplicaron los cuestionarios a comerciantes de totomoxtle (triángulos rojos) y a productores de totomoxtle (azul).

Figure 1. Location of places where questionnaires were applied to totomoxtle sellers (red triangles) and totomoxtle producers (blue areas). 


\section{Instrumento empleado}

Para el caso de los comerciantes, el cuestionario constó de 20 preguntas (nueve cerradas y 11 abiertas), las cuales estuvieron relacionadas con el origen y las características físicas del totomoxtle, el volumen, la venta, así como el beneficio económico obtenido por la venta de totomoxtle. A los productores se les aplicó un cuestionario constituido por 39 preguntas (29 abiertas y 10 cerradas), y se enfocaron a documentar información socioeconómica del productor, la superficie destinada al cultivo de maíz, los costos de producción, la producción total obtenida y las características físicas del totomoxtle. Los cuestionarios se aplicaron en 2011.

\section{Análisis estadístico}

La información obtenida de cada tipo de cuestionario se concentró en una hoja de cálculo de Excel $^{\circledR}$. En el caso de los datos de comerciantes, se procesó la información para obtener diversos estadísticos descriptivos e identificar las principales localidades donde se aprovecha el totomoxtle dentro de cada región del estado de Puebla. En lo que se refiere a los cuestionarios aplicados a productores de totomoxtle, la información se codificó para obtener una matriz de datos que constó de 14 variables cuantitativas la cual se sometió a un análisis de Componentes Principales. Posteriormente se calculó una matriz de distancias con la cual se efectuó un análisis de conglomerados con el procedimiento PROC CLUSTER del paquete SAS versión 8.0 para Windows (SAS Institute, 2008); visualizando los patrones de agrupamiento mediante la elaboración de un dendrograma, con el procedimiento PROC TREE del SAS. El método de agrupamiento aplicado fue el de mínima varianza dentro de grupos de Ward, y para mejorar la presentación de la gráfica se utilizó el coeficiente de determinación como escala de disimilitud entre conglomerados (Mohammadi y Prasanna, 2003). Se condujo un análisis de varianza y una prueba de medias para los grupos identificados en el dendrograma. Por último, se realizó un análisis de correspondencias simple, una técnica multivariada empleada para representar en un espacio geométrico de escasas dimensiones las proximidades existentes entre un conjunto de objetos, sujetos o estímulos; este análisis se llevó a cabo con el procedimiento PROC CORRESP de SAS. Para el among their products. With the results, the main totomoxtle producing and selling localities were identified, which allowed performing the second stage that consisted in applying questionnaires directed at totomoxtle producers in the localities of San Francisco Cuautlancingo, municipality of Chalchicomula de Sesma (Serdán region); Atzala and Calpan, from the municipality of Calpan, and Tepatlaxco de Hidalgo, municipality of the same name, all of these in the Puebla region. The same was performed in the localities of San José Miahuatlán and Altepexi, belonging to municipalities of the same name, in the Tehuacán region (Figure 1). Applying the non-probabilistic sample known as "snowball", a total of 47 producers were sampled, distributed in the following way: six in San Francisco Cuautlancingo, eight in Atzala, eight in Calpan, 15 in Tepetlaxco de Hidalgo, five in San José Miahuatlán, and five in Altepexi.

\section{Instrument Used}

For the case of sellers, the questionnaire had 20 questions (nine closed and 11 open), which were related with the origin and the physical characteristics of totomoxtle, the volume, the sale, as well as the economic benefit obtained from the sale of totomoxtle. A questionnaire was applied to the producers that consisted of 39 questions (29 open and 10 closed), and they focused on documenting socioeconomic information of the producer, the surface destined to maize cultivation, the production costs, the total production obtained, and the physical characteristics of totomoxtle. The questionnaires were applied in 2011.

\section{Statistical Analysis}

The information obtained from each type of questionnaire was concentrated in an Excel $^{\oplus}$ worksheet. In the case of the data of sellers, the information was processed to obtain various descriptive statistics and to identify the main localities where totomoxtle is used inside each region of the state of Puebla. Concerning the questionnaires applied to totomoxtle producers, the information was codified to obtain a data matrix that had 14 quantitative variables, which was subjected to a Principal Components Analysis. 
análisis de conglomerados y el de correspondencia se sumaron seis variables cualitativas de interés a las 14 variables cuantitativas mencionadas previamente.

\section{RESULTADOS Y DISCUSIÓN}

Los cuestionarios aplicados a comerciantes de totomoxtle revelaron que un alto porcentaje del producto que se comercializa en los mercados de Huejotzingo, Central de Abastos de Puebla, Cholula, Tehuacán y Chalchicomula de Sesma, proviene de localidades relativamente cercanas a cada mercado (Figuras 1 y 2). También se observó que en todos los casos hay una localidad que destaca por su aporte al volumen total comercializado (Figura 2), tal es el caso de Atzala (municipio de Calpan) en los mercados de Huejotzingo y Cholula; Tepatlaxco de Hidalgo (municipio del mismo nombre) en la Central de Abastos; San José Miahuatlán (municipio del mismo nombre) en Tehuacán y San Francisco Cuautlancingo (municipio de Chalchicomula de Sesma) en el último mercado. Lo anterior sugiere que algunos productores de maíz, en localidades muy específicas, están aprovechando la existencia de un mercado para
Then, a distance matrix was calculated with which a cluster analysis was carried out with the PROC CLUSTER procedure from the SAS package version 8.0 for Windows (SAS Institute, 2008), visualizing the grouping patterns through the elaboration of a dendrogram, with the PROC TREE procedure from SAS. The grouping method applied was the Ward's minimum variance method, and to improve the presentation of the graph, the determination coefficient was used as a scale of dissimilarity between conglomerates (Mohammadi and Prasanna, 2003). A variance analysis and a means test were conducted for the groups identified in the dendrogram. Lastly, a simple correspondence analysis was performed, which is a multivariate technique used to represent in a geometric space of small dimensions the existing proximities between a set of objects, subjects or stimuli; this analysis was carried out with the PROC CORRESP procedure from SAS. For the cluster analysis and the correspondence analysis, six qualitative variables of interest were added to the 14 quantitative variables mentioned previously.

Localidades

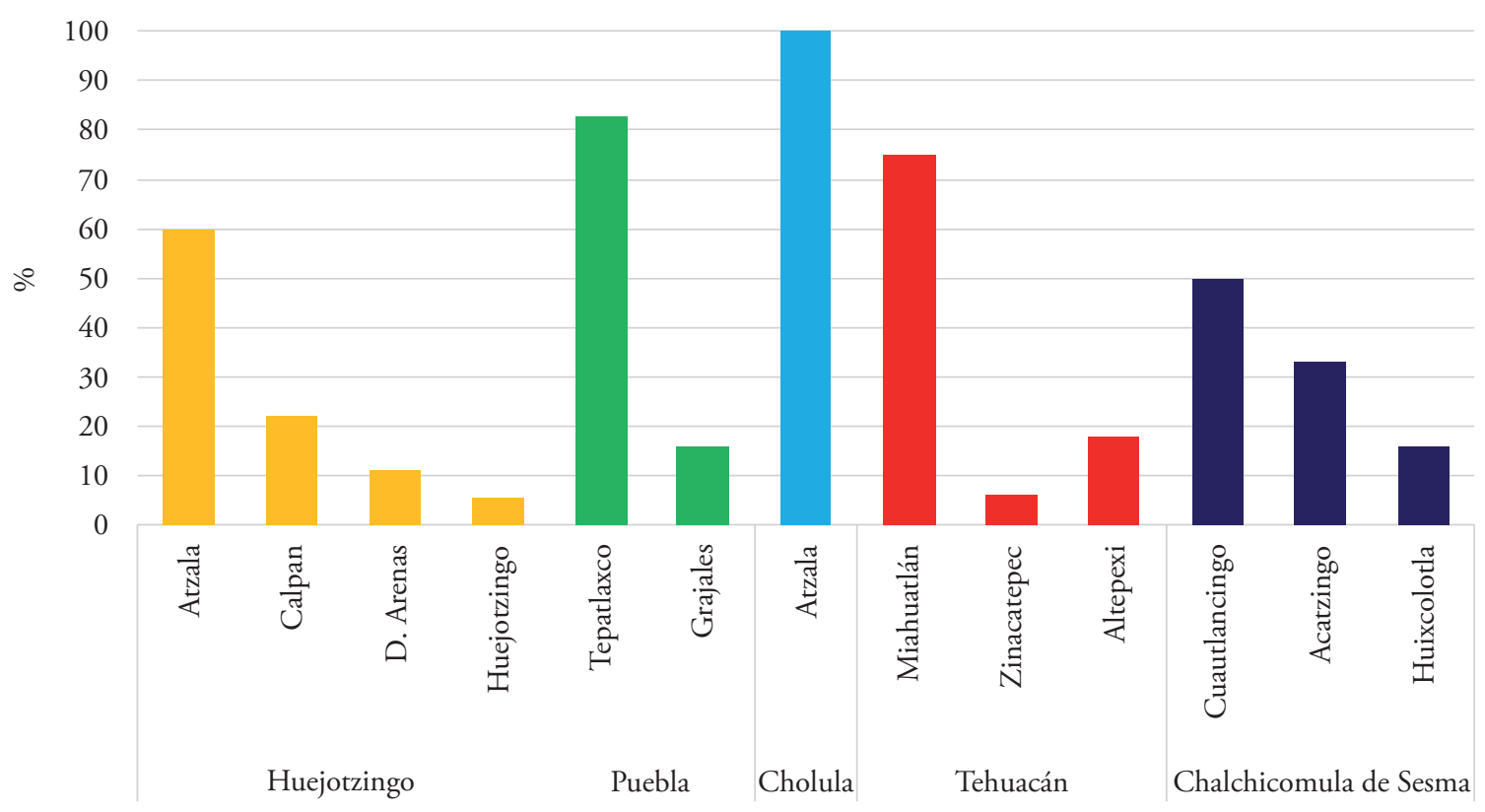

Mercados

Figura 2. Localidades que abastecen a los principales mercados comercializadores de totomoxtle en el estado de Puebla, México, 2011. Figure 2. Localities that supply the main totomoxtle selling markets in the state of Puebla, Mexico, 2011. 
el totomoxtle para emplear éste como una estrategia que les permite aumentar los ingresos derivados del cultivo. Ello concuerda con el planteamiento de Keleman y Hellin (2009), quienes mencionan que los productores de maíz, pequeños y medianos, han procurado aprovechar los diversos productos derivados del cereal y los comercializan en mercados especializados. Quizá esta estrategia ha permitido compensar en parte el impacto negativo del neoliberalismo y del Tratado de Libre Comercio de América del Norte sobre la producción de maíz de los pequeños agricultores (Eakin et al., 2014),

En lo que se refiere a cómo los comerciantes de totomoxtle acopian los volúmenes que venden, se encontró que $52 \%$, debido a que también son productores de maíz, aprovechan el totomoxtle cosechado en sus parcelas y lo llevan a vender de manera directa a los mercados locales que se encuentren cercanos a sus comunidades; un $27 \%$ indicó que compra el totomoxtle con productores de su misma localidad para comercializarlo de igual manera en los mercados locales y regionales, y $21 \%$ señaló que además de aprovechar el totomoxtle de sus parcelas, compra totomoxtle con productores de su localidad para comercializar un mayor volumen.

Un análisis más detallado de los resultados indicó que el porcentaje de comerciantes de totomoxtle que además lo produce varió dependiendo del mercado. Así, en el mercado de Cholula, 100\% de los vendedores son productores que comercializan de manera directa el totomoxtle que producen. En Huejotzingo, $78 \%$ es productor, $11 \%$ comprador y $11 \%$ productor y comprador de totomoxtle. En la central de abastos de la ciudad de Puebla, 33\% de los entrevistados produce y aprovecha el totomoxtle a través de su venta directa en la central, $33 \%$ es productor y comprador, y $34 \%$ sólo se dedica a comprar y re-vender este derivado del maíz. En el mercado de Tehuacán, sólo 12\% es productor de totomoxtle, $50 \%$ es re-vendedor y $38 \%$ es productor pero también comprador. La razón por la cual hay productores de maíz que también venden directamente el totomoxtle que producen puede encontrarse en lo expuesto por Keleman y Hellin (2009), quienes apuntan que el hecho de comercializar productos del maíz en mercados especializados puede reportar un beneficio neto por hectárea que equivale al doble del que obtienen los productores que venden el grano de maíz en los mercados de productos comerciales. Esto además explica la existencia

\section{RESULTS AND DISCUSSION}

The questionnaires applied to totomoxtle sellers revealed that a high percentage of the product that is sold in the markets of Huejotzingo, Puebla's wholesale market, Cholula, Tehuacán and Chalchicomula de Sesma, comes from localities that are relatively near to each market (Figures 1 and 2). It was also observed that in every case, there is a locality that stands out for its contribution to the total volume sold (Figure 2), as is the case of Atzala (municipality of Calpan) in the markets of Huejotzingo and Cholula; Tepatlaxco de Hidalgo (municipality of the same name) in the wholesale market; San José Miahuatlán (municipality of the same name) in Tehuacán, and San Francisco Cuautlancingo (municipality of Chalchicomula de Sesma) in the last market. This suggests that some maize producers, in very specific localities, are taking advantage of the existence of a market for totomoxtle to use it as a strategy that allows them to increase the income derived from the crop. This agrees with the suggestion by Keleman and Hellin (2009), who mentioned that the small and medium scale maize producers have attempted to take advantage of the various products derived from the cereal and sell them in specialized markets. Perhaps this strategy has allowed compensating in part the negative impact of Neoliberalism and the North American Free Trade Agreement on maize production of small-scale farmers (Eakin et al., 2014).

In terms of how totomoxtle sellers collect the volumes that they sell, it was found that $52 \%$ use the totomoxtle harvested in their plots, because they also are maize producers, and they take it to sell directly in the local markets that are close to their communities; $27 \%$ indicated that they buy totomoxtle with producers of their same locality to sell it also in the local and regional markets; and $21 \%$ pointed out that in addition to using totomoxtle from their plots, they also buy totomoxtle from producers in their locality in order to sell a higher volume.

A more detailed analysis of the results indicated that the percentage of totomoxtle sellers that also produce it, varied depending on the market. Thus, in the Cholula market, $100 \%$ of the sellers are producers who directly sell the totomoxtle they produce. In Huejotzingo, $78 \%$ are producers, $11 \%$ buyers and $11 \%$ producers and buyers of 
de productores de maíz que no sólo comercializan el totomoxtle producido por ellos mismos, sino que en algunos casos también participan como compradores del producto para su reventa.

Los productores de las regiones evaluadas perciben la producción y venta de totomoxtle como una actividad generadora de ingresos, lo que concuerda con lo reportado por Viveros-Flores et al. (2010). Notablemente, dicha actividad no se ha convertido en su principal fuente de ingresos, como es el caso de la zona totonaca de Veracruz, donde la producción de totomoxtle se ha constituido en la opción más rentable para los agricultores (King, 2007). Aunque la mayoría de los agricultores siguen produciendo maíz para el consumo de los hogares, la comercialización del totomoxtle representa un incentivo adicional e importante para seguir aprovechando y mantener o aumentar la producción de maíz.

En esta investigación también se estudiaron las características físicas del totomoxtle que lo hacen deseable para su comercialización. La mayor parte de los vendedores de los cinco mercados mencionaron que el totomoxtle debe estar en buen estado y ser de color blanco, debido a que es más solicitado (muy pocos mencionaron la preferencia por el totomoxtle de color morado). Las brácteas deben ser anchas, largas, de textura suave y no rígida ni quebradiza porque dificultarían su manejo, y deben de estar completas, ya que las emplean para la elaboración de tamales. Características similares son aplicadas en lugares en donde un volumen importante de totomoxtle se procesa para fines de exportación, como ocurre en $\mathrm{Na}$ yarit (Hernández-Guzmán y Parra, 2007); estado en el que dichas características se utilizan para clasificar las brácteas del maíz en distintas categorías, lo que les confiere un valor diferencial en el mercado nacional y de exportación.

Con respecto a la presentación para la venta, ésta varía de acuerdo a las regiones. En el tianguis de Tehuacán, el totomoxtle se vende en rollos, acomodados en una bolsa denominada arpilla, la cual contiene de 230 a 240 hojas aproximadamente. En el mercado de Chalchicomula de Sesma, los paquetes constan de varios rollos; en promedio un paquete contiene 173 hojas. En los demás mercados de la región de Puebla, la presentación de venta es en rollos, con un promedio de 68 hojas por rollo, aunque en el mercado de Cholula el promedio fue de 58 hojas por unidad. Esto difiere con lo reportado por Andrés-Meza et al. totomoxtle. In the wholesale market of the city of Puebla, 33\% of interview respondents produce and use totomoxtle through their direct sale in the wholesale market, $33 \%$ are producers and buyers, and $34 \%$ are only devoted to buying and reselling this maize byproduct. In the Tehuacán market, only $12 \%$ are totomoxtle producers, $50 \%$ resellers and $38 \%$ producers but also buyers. The reason why there are maize producers who also sell directly the totomoxtle they produce can be found in what was exposed by Keleman and Hellin (2009), who point to the fact that selling maize products in specialized markets can obtain a net benefit per hectare that is twice that obtained by producers who sell corn grain in commercial products markets. This also explains the existence of maize producers who not only sell the totomoxtle they produce, but rather who in some cases also participate as buyers of the product for its resell.

The producers of the evaluated regions perceive the production and sale of totomoxtle as an activity that generates income, which agrees with what was reported by Viveros-Flores et al. (2010). Notably, this activity has not become their main source of income as is the case of the Totonaca zone of Veracruz, where totomoxtle production has become the most profitable option for farmers (King, 2007). Although most of the farmers continue producing maize for household consumption, the commercialization of totomoxtle represents an additional and important incentive to continue using and maintaining or increasing maize production.

In this study, the physical characteristics of totomoxtle that make it desirable for its commercialization are studied. Most of the sellers from the five markets mentioned that totomoxtle should be in a good state and be of white color, because it is the most frequently requested (very few mentioned the preference for totomoxtle of purple color). The bracts should be wide, long, of soft texture and not rigid or brittle because that would make handling them more difficult, and they should be complete, since they use it to make tamales. Similar characteristics are applied in places where an important volume of totomoxtle is processed for export purposes, as it happens in Nayarit (Hernández-Guzmán and Parra, 2007), state where these characteristics are used to classify the maize bracts (cornhusks) into different categories, giving them a differential value in the national and exports market. 
(2014), quienes señalan que un rollo de totomoxtle contiene 80 hojas de maíz.

En relación a los meses de mayor venta de totomoxtle, la mayoría de los vendedores, coinciden en que son noviembre, diciembre y febrero, debido a las fiestas de Todos Santos (1 y 2 de noviembre), fiestas decembrinas y el día de la Candelaria (2 de febrero), respectivamente. En esas temporadas las ventas aumentan al doble y al triple, particularmente en los mercados de Tehuacán y Chalchicomula de Sesma, y en consecuencia, los ingresos también. En cuanto a la perspectiva que tienen los vendedores respecto a las ventas para los próximos tres años (2012-2014), 50\% consideró que las ventas se mantendrán constantes, 45\% opinó que disminuirán y sólo 5\% piensa que aumentarán.

Con relación a los resultados del estudio dirigido a productores de totomoxtle, se encontró que las razones por las cuales aprovechan dicho producto fueron: a) porque es una actividad que realizan por costumbre $(77 \%)$; b) porque existe mercado para su comercialización $(13.5 \%)$; c) para obtener ingresos adicionales por su venta (7\%); y d) porque a su regreso de los Estados Unidos no tenía otra actividad y era una que ya realizaba antes de migrar (2.5\%). Al preguntar a los productores sobre el valor que le dan a la producción de maíz y a la del totomoxtle, 13\% opinó que el cultivo de maíz es importante sólo por la producción de grano, $11 \%$ señaló que es más importante la producción de totomoxtle, mientras que $76 \%$ afirmó que la producción de grano y totomoxtle tienen la misma importancia.

En lo que respecta al proceso de extracción de totomoxtle, de los encuestados de las tres regiones $100 \%$ respondió que emplean mano de obra familiar y hacen la extracción de forma manual. Esta es una característica propia de la mayoría de los pequeños agricultores, para quienes el empleo de la mano de obra familiar es considerada una estrategia de vida (Toledo et al., 2006). Esta actividad demanda gran cantidad de mano de obra, ya que una persona diestra sólo es capaz de deshojar de 60 a 80 mazorcas por hora (Cruz-Meza et al., 2010), por lo que de requerirse contratar jornales, los costos para la extracción del totomoxtle tendrían un incremento considerable.

La extracción manual del totomoxtle contrasta con la modalidad encontrada en otras regiones del país en las cuales ya existe un aprovechamiento más industrial del mismo, como es el caso de Jalisco, en
Regarding the presentation for sale, it varies according to the regions. In the Tehuacán tianguis, totomoxtle is sold in rolls, arranged in a bag called arpilla, which contains 230 to 240 cornhusks approximately. In the market of Chalchicomula de Sesma, the packages have several rolls, and on average one package contains 173 cornhusks. In the other markets of the Puebla region, the presentation for sale is in rolls, with an average of 68 cornhusks per roll, although in the Cholula market the average was 58 cornhusks per unit. This differs from what was reported by Andrés-Meza et al. (2014), who point out that a totomoxtle roll contains 80 maize cornhusks.

Regarding the months of highest sale of totomoxtle, most of the sellers agree that those are November, December and February, due to the festivities of Todos Santos (November 1 and 2), December celebrations, and the day of Candelaria (February 2), respectively. In these seasons the sale doubles and triples, particularly in the Tehuacán and Chalchicomula de Sesma markets, and consequently also the income. In terms of the perspective that sellers have regarding the sales for the next three years (2012-2014), 50\% considered that the sales will remain constant, $45 \%$ were of the opinion that they would decrease, and only 5\% thought they would increase.

In relation to the results from the study directed at totomoxtle producers, it was found that the reasons why they use this product were: a) because it is an activity that they usually do (77\%); b) because there is a market for its commercialization $(13.5 \%)$; c) to obtain additional income from its sale (7\%); and d) because when they returned from the United States they did not have another activity and it was one that they already performed before migrating (2.5\%). When asking the producers about the value that they give to maize and totomoxtle production, $13 \%$ were of the opinion that maize cultivation is important only because of grain production, $11 \%$ pointed out that totomoxtle production is more important, while $76 \%$ stated that grain and totomoxtle production have the same importance.

Regarding the process of totomoxtle extraction, $100 \%$ of the survey respondents from the three regions answered that they use family labor and carry out the extraction manually. This is a characteristic of small-scale producers, for whom employing family 
donde hay plantas de acopio y empaquetamiento, y la manera de obtener totomoxtle es mediante los denominados cuadrilleros a través de sus líderes, quienes hacen acuerdos con los propietarios del cultivo de maíz para cosecharles de manera gratuita y obtener a cambio el derecho de aprovechar el totomoxtle (Long y Villarreal, 1998); algo similar ocurre en Nayarit (Rice, 2007). En éste estado, el totomoxtle se extrae utilizando discos de acero afilados en su interior y montados en bancos de madera, con lo cual los productores cortan la base del totomoxtle antes de retirarlo de la mazorca, para de allí proceder a su procesamiento (Hernández-Guzmán y Parra, 2007). De acuerdo a lo visto en campo, un esquema análogo empieza a tener lugar en la región de Tehuacán, aunque dicha información aún no se ha sistematizado en la literatura científica. Es pertinente mencionar que existen en México algunas máquinas diseñadas para extraer el totomoxtle y realizar a la vez el desgrane del maíz, pero su uso actual es limitado debido al daño mecánico que ocasionan al totomoxtle (Cruz-Meza et al., 2010).

Para la comercialización del totomoxtle, son los propios productores quienes seleccionan las hojas más grandes, enteras y que no se encuentren maltratadas. En algunos casos son ellos quienes llevan a vender el totomoxtle a los mercados regionales más cercanos. En el municipio de Tepatlaxco, 50\% de los productores lleva a vender el totomoxtle a la central de abastos de la ciudad de Puebla y 50\% lo vende a algún familiar que se dedica a la comercialización de totomoxtle. En la región de Tehuacán, 60\% de los productores le venden el totomoxtle a algún acopiador que llega a la zona o de la misma región y $40 \%$ lo vende de forma directa en los mercados regionales. En la región de Serdán, 90\% lo vende a algún familiar que se dedica a la comercialización en otras regiones o estados, mientras que $10 \%$ lo hace de forma directa en el mercado regional.

En el aspecto económico, los mayores costos de producción de maíz por hectárea los presentó la región de Tehuacán (Cuadro 1), ya que ahí los productores invierten el doble de lo registrado en las demás regiones. Ello se debe a que el sistema de producción es de riego, por lo cual el productor tiene que comprar horas de agua para riego (sistema local de venta de agua). No obstante, conviene mencionar que esta disponibilidad de agua les da la posibilidad de tener dos ciclos de cultivo de maíz al año. Con labor is considered a life strategy (Toledo et al., 2006). This activity demands a large amount of labor, since one skilled person is only able to defoliate 60 to 80 ears per hour (Cruz-Meza et al., 2010), so if they were to require hiring day laborers, the costs for the extraction of totomoxtle would have a considerable increase.

The manual extraction of totomoxtle contrasts with the modality found in other regions of the country, where there is already a more industrial use of it, as is the case of Jalisco, where there are gathering and packaging plants, and the way of obtaining totomoxtle is by means of so-called cuadrilleros through their leaders, who make agreements with the maize crop owners to harvest them for free and to obtain in exchange the right to use the totomoxtle (Long and Villarreal, 1998); something similar happens in Nayarit (Rice, 2007). In Nayarit, the totomoxtle is extracted using steel discs sharpened inside and mounted on wooden workbenches, with which producers cut the base of the totomoxtle before withdrawing it from the ear, in order to continue with its processing (Hernández-Guzmán and Parra, 2007). According to what was seen in the field, an analogue scheme begins to take place in the Tehuacán region, although this information has still not been systematized in the scientific literature. It is worth mentioning that in Mexico there are some machines designed to extract totomoxtle and to perform at the same time maize de-kernelling, but their current use is limited due to the mechanical damage that they cause to totomoxtle (Cruz-Meza et al., 2010).

For totomoxtle commercialization, the producers themselves are the ones who select the largest whole cornhusks that are not damaged. In some cases, it is they who take the totomoxtle to sell in the closest regional markets. In the municipality of Tepatlaxco, $50 \%$ of the producers take totomoxtle to sell at the wholesale market in the city of Puebla and 50\% sell it to some relative who is devoted to totomoxtle trade. In the Tehuacán region, $60 \%$ of the producers sell totomoxtle to some collector who reaches the zone or from the same region and $40 \%$ sells it directly in regional markets. In the Serdán region, $90 \%$ sells it to some relative who is devoted to commercialization in other regions or states, while $10 \%$ does it directly in the regional market.

In the economic aspect, the highest maize production costs per hectare were found in the 
Cuadro 1. Análisis económico derivado de la encuesta a cuarenta y siete productores de totomoxtle en tres regiones del estado de Puebla, México, 2011.

Table 1. Economic analysis derived from the survey with forty-seven totomoxtle producers in three regions of the state of Puebla, Mexico, 2011.

\begin{tabular}{|c|c|c|c|c|c|c|}
\hline \multirow{2}{*}{ Variable } & \multicolumn{2}{|c|}{ Región Puebla } & \multicolumn{2}{|c|}{ Región Tehuacán } & \multicolumn{2}{|c|}{ Región Serdán } \\
\hline & Atzala & Calpan & Tepatlaxco & Altepexi & Miahuatlán & Cuautla $^{\dagger}$ \\
\hline Valor de $\mathrm{n}$ & 8 & 8 & 15 & 5 & 5 & 6 \\
\hline Producción $\mathrm{GR}^{\dagger \dagger}\left(\mathrm{t} \mathrm{ha}^{-1}\right)$ & 1.6 & 1.0 & 2.0 & 2.5 & 2.6 & 1.4 \\
\hline Producción TT (Rollos/ha) & 240 & 300 & 526 & 2200 & 264 & 693 \\
\hline Costo de producción $(\$ / h a)$ & 6375 & 6187 & 9670 & 13020 & 12160 & 6342 \\
\hline Precio de venta GR $(\$ / \mathrm{kg})$ & 4.5 & 4.5 & 4.8 & 5.0 & 4.6 & 5.0 \\
\hline Precio de venta TT (\$/rollo) & 10.7 & 10.0 & 7.0 & 4.0 & 5.3 & 11.3 \\
\hline Beneficio/Costo para GR & 0.287 & 0.807 & 0.980 & 0.989 & 1.028 & 1.241 \\
\hline Beneficio/Costo GR y TT & 0.459 & 1.021 & 1.094 & 1.298 & 1.113 & 1.565 \\
\hline
\end{tabular}

${ }^{\dagger}$ Cuautla: Cuautlancingo, ${ }^{\dagger}$ GR: Grano, 'TT: Totomoxtle. * ${ }^{\dagger}$ Cuautla: Cuautlancingo, ${ }^{\dagger \dagger}$ GR: Grain, 'TT: Totomoxtle.

los datos obtenidos se calculó la relación BeneficioCosto (B/C) la cual, para considerarse aceptable debe ser mayor o igual a uno. Cuando los productores sólo venden maíz, 59.6\% de ellos, en las tres regiones, obtienen un indicador menor a uno, lo que se traduce en pérdidas, excepto en Atzala, Miahuatlán y Cuautlancingo. Por el contrario, cuando se obtiene el indicador incluyendo la venta de totomoxtle, en todas las regiones y comunidades se reporta una relación $\mathrm{B} / \mathrm{C}$ mayor a uno, siendo las comunidades más favorecidas las de Cuautlancingo, Atzala y Altepexi (Cuadro 1). Con base en ese indicador, cuando se aprovechó el totomoxtle, el beneficio se incrementó entre 8.3 y $31.2 \%$ respecto a cuándo sólo se aprovechó el grano del maíz. Esto es congruente con lo afirmado por Keleman et al. (2013), quienes reportan que la venta de totomoxtle es el segundo factor que más contribuye a los ingresos de los productores, seguido del elote $y$, finalmente, el forraje.

Con base en lo anterior se puede afirmar que el ingreso generado por el totomoxtle tiene impactos importantes en términos de incentivos para continuar la producción de maíz en las regiones estudiadas, y que su aprovechamiento favorece la conservación de la diversidad local de maíz, ya que el 100\% de los agricultores que comercializan el totomoxtle señalaron utilizar únicamente semilla de poblaciones nativas. Esto quizá se debe a que, como lo señalan respectivamente Rice (2007) y King (2007) para el caso de los estados de Nayarit y Veracruz, en estos lugares las poblaciones nativas de maíz presentan mejor calidad en cobertura de la mazorca y rendimiento de totomoxtle que los híbridos. Algo similar encontraron Flores-Rosales et
Tehuacán region (Table 1), since the producers there invest twice the amount that what was found in the other regions. This is because the production system depends on irrigation, for which the producer has to buy hours of irrigation water (local system for water sale). However, it is worth mentioning that this water availability gives them the possibility of having two cycles of maize cultivation per year. With the data obtained the benefit-cost rate $(\mathrm{B} / \mathrm{C})$ was calculated, which in order to be considered acceptable should be higher or equal to one. When the producers only sell maize, $59.6 \%$ of them, in the three regions, obtain an indicator lower than one, which translates into losses, except in Atzala, Miahuatlán and Cuautlancingo. On the contrary, when the indicator is obtained including the sale of totomoxtle, a B/C rate higher than one is reported in every region and community, with the most favored communities being Cuautlancingo, Atzala and Altepexi (Table 1). Based on this indicator, when totomoxtle was used, the benefit increased between 8.3 and $31.2 \%$ compared to when only maize grain was used. This agrees with what Keleman et al. (2013) stated, who report that the sale of totomoxtle is the second factor that contributes most to producers' income, followed by corn on the cob and, finally, fodder.

Based on this, it can be affirmed that the income generated by totomoxtle has important impacts in terms of incentives to continue maize production in the regions studied, and that its use favors the conservation of local maize diversity, since 100\% of the farmers who sell totomoxtle point to using solely seed from native populations. This is perhaps 
al. (2015), quienes reportaron que las poblaciones nativas de maíz en tres regiones del estado de Puebla fueron las que tuvieron mejor comportamiento en las diferentes variables de totomoxtle evaluadas, por lo que sugieren que este tipo de poblaciones son las que deben considerarse como punto de partida en programas de aprovechamiento y mejoramiento para producción de totomoxtle. Este es un comportamiento que ocurre con la mayoría de los agricultores que cuentan con pequeñas superficies, como en el sureste de México, donde los agricultores mantienen diferentes variedades de maíz que están adaptadas a diversas calidades de suelo (Bellon y Taylor, 1993) o que tienen la capacidad de enfrentar los distintos regímenes higrotérmicos y ambientales en que se cultivan (Muñoz, 2005). Además, en México, para los agricultores es una decisión difícil y compleja el invertir en semilla debido a que la semilla híbrida puede costar hasta cinco veces más que la semilla de las poblaciones nativas locales (Keleman et al., 2013). En cuanto al potencial para la producción de totomoxtle, destacaron las localidades de la región de Tehuacán (Cuadro 1), lo cual concuerda con lo reportado por Flores-Rosales et al. (2015).

El análisis de componentes principales reveló que los tres primeros componentes (TOT1, TOT2 y TOT3) explicaron $68.61 \%$ de la variación observada entre productores de totomoxtle (Cuadro 2). El Cuadro 2 muestra que las variables con mayor influencia para el primer componente fueron beneficio total (venta de grano y totomoxtle), venta de maíz como grano y ganancia por la venta de grano. El segundo componente quedó explicado en mayor medida por los años que el productor tiene sembrando maíz, los años que tiene comercializando totomoxtle y por la edad del productor. Las variables originales de mayor importancia en el caso del tercer componente fueron el costo por hectárea sembrada con maíz en 2011, la producción de grano y la superficie sembrada con maíz en ese mismo año. Lo anterior evidencia que las diferencias entre productores se deben en gran medida, a tres conjuntos de variables: las económicas (asociadas a la ganancia derivada de la venta de productos del maíz), las productivas, y las asociadas con el tiempo dedicado a la producción y aprovechamiento del totomoxtle.

En el dendograma generado (Figura 3), al realizar un corte a una altura de 0.075 unidades, se definieron cuatro grupos: el Grupo I concentró a 10 productores, $90 \%$ de ellos perteneciente a la región de because, as Rice (2007) and King (2007) respectively point out for the cases of the states of Nayarit and Veracruz, in these places the native maize populations have better quality in ear cover and totomoxtle yield than hybrids. Something similar was found by Flores-Rosales et al. (2015), who reported that the native maize populations in three regions of the state of Puebla were the ones that had best performance in the different variables of totomoxtle evaluated, so they suggest that this type of populations are the ones that ought to be considered as starting point in programs for using and improving totomoxtle production. This is a behavior that happens with most of the farmers who own small surfaces, as in the southeastern region of Mexico, where farmers keep different maize populations that are adapted to different soil qualities (Bellon and Taylor, 1993), or which have the ability to face the different hygrothermal and environmental regimes in which they are cultivated (Muñoz, 2005). In addition, in Mexico, for the farmers it is a difficult and complex decision to invest in seeds because the hybrid seed can cost up to five times more than the seed from local native populations (Keleman et al., 2013). Regarding the potential for totomoxtle production, the localities from the Tehuacán region stood out (Table 1), which agrees with what was reported by Flores-Rosales et al. (2015).

The principal components analysis revealed that the three first components (TOT1, TOT2 and TOT3) explained $68.61 \%$ of the variation observed among totomoxtle producers (Table 2). Table 2 shows that the variables with greatest influence for the first component were total benefit (grain and totomoxtle sale), maize grain sale, and profit from grain sale. The second component was explained largely by the years that producers have been sowing maize, the years they have sold totomoxtle, and the producer's age. The original variables of greatest importance in the case of the third component were cost per hectare sown with maize in 2011, grain production, and surface sown with maize in that same year. This evidences that the differences between producers are due mainly to three sets of variables: the economic (associated to the profit derived from the sale of maize products), the productive, and those associated with the time devoted to totomoxtle production and use.

In the dendogram generated (Figure 3), when performing a cut at 0.075 units, four groups were 
Cuadro 2. Vectores propios y valores propios para los tres primeros componentes principales (TOT) derivados de información de productores de totomoxtle del estado de Puebla, México, 2011.

Table 2. Eigenvalues and eigenvectors for the three first principal components (TOT) derived from information of totomoxtle producers in the state of Puebla, Mexico, 2011.

\begin{tabular}{|c|c|c|c|}
\hline \multirow{2}{*}{ Variable } & \multicolumn{3}{|c|}{ Componente Principal } \\
\hline & TOT1 & TOT2 & TOT3 \\
\hline Edad del productor (años) & -0.09 & 0.56 & -0.06 \\
\hline Tiempo del productor sembrando maíz (años) & -0.02 & 0.58 & -0.06 \\
\hline Superficie sembrada con maíz en 2011 (ha) & 0.30 & -0.04 & -0.41 \\
\hline Producción de grano en $2011(\mathrm{t})$ & 0.28 & 0.06 & 0.50 \\
\hline Venta de maíz como grano $(\mathrm{t})$ & 0.39 & -0.02 & 0.08 \\
\hline Grano para autoconsumo $(\mathrm{t})$ & 0.20 & 0.05 & -0.28 \\
\hline Uso del maíz como semilla $(\mathrm{k})$ & 0.02 & 0.04 & 0.29 \\
\hline Consumo animal $(\mathrm{t})$ & 0.25 & 0.10 & 0.19 \\
\hline Costo de producción por ha en $2011(\$)$ & 0.25 & -0.04 & 0.52 \\
\hline Ganancia por la venta de grano $(\$)$ & 0.38 & 0.02 & -0.11 \\
\hline Años comercializando totomoxtle & -0.02 & 0.56 & 0.08 \\
\hline Producción total de totomoxtle (rollos) & 0.33 & 0.08 & -0.01 \\
\hline Ganancia por la venta de totomoxtle $(\$)$ & 0.31 & 0.03 & -0.23 \\
\hline Beneficio por la venta de grano y totomoxtle $(\$)$ & 0.41 & 0.03 & -0.17 \\
\hline Valor propio & 5.45 & 2.71 & 1.45 \\
\hline Proporción de variación explicada (\%) & 38.95 & 19.33 & 10.34 \\
\hline
\end{tabular}

Puebla y $10 \%$ a la de Tehuacán; el Grupo II incluyó a 20 agricultores, de los cuales $65 \%$ fueron de la región de Puebla, $20 \%$ de la de Tehuacán y $15 \%$ de la de Serdán; el Grupo III concentró a 14 del total e incluyó a productores de la región de Puebla (64.3\%), Serdán (21.4\%) y Tehuacán (14.3\%). Finalmente, el Grupo IV aglutinó a tres de los productores entrevistados, todos de Altepexi, región Tehuacán. Destacan los Grupos II y III, y en menor grado el Grupo I, dentro de los cuales quedaron incluidos productores de regiones distintas. En general, los productores concentrados en estos grupos fueron aquellos que en promedio obtuvieron la menor producción de grano de maíz en 2011 (PRODGR), la menor parte del cual se destinó al consumo animal (CANI); produjeron el menor volumen de rollos de totomoxtle (PROTOTOT), obtuvieron las ganancias más bajas por la venta de totomoxtle (INGTOTAL) y el menor beneficio por la venta conjunta de grano y totomoxtle (BENTOTAL) (Cuadro 3). Lo contrario ocurrió con los productores aglutinados en el Grupo IV.

De acuerdo con la información del Cuadro 3, el grupo I se caracterizó por aglutinar productores con la menor superficie cultivada con maíz en 2011, los más bajos costos de producción, volúmenes similares de grano destinado al autoconsumo y venta, poca ganancia por la venta de grano, baja producción de rollos de defined: Group I concentrated 10 producers, 90\% of them belonged to the Puebla region and $10 \%$ to Tehuacán; Group II included 20 farmers, of whom $65 \%$ were in the Puebla region, 20\% in Tehuacán and $15 \%$ in Serdán; Group III concentrated 14 of the total and included producers from the region of Puebla (64.3\%), Serdán (21.4\%) and Tehuacán (14.3\%). Finally, Group IV gathered three of the producers interviewed, all from Altepexi, Tehuacán region. Groups II and III stand out, and to a lesser degree Group I, within which producers from different regions were included. In general, the producers concentrated in the groups I, II, and III were those that on average obtained the lowest maize grain production in 2011 (PRODGR), the least part of which was destined to animal consumption (CANI); they produced the lowest volume of totomoxtle rolls (PROTOTOT), obtained the lowest profits from the sale of totomoxtle (INGTOTAL), and the lowest benefit from the joint sale of grain and totomoxtle (BENTOTAL) (Table 3). The opposite happened with the producers gathered in Group IV.

According to the information from Table 3, Group I was characterized by bringing together producers with the smallest surface cultivated with maize in 2011, the lowest production costs, similar grain volumes destined to auto-consumption and 


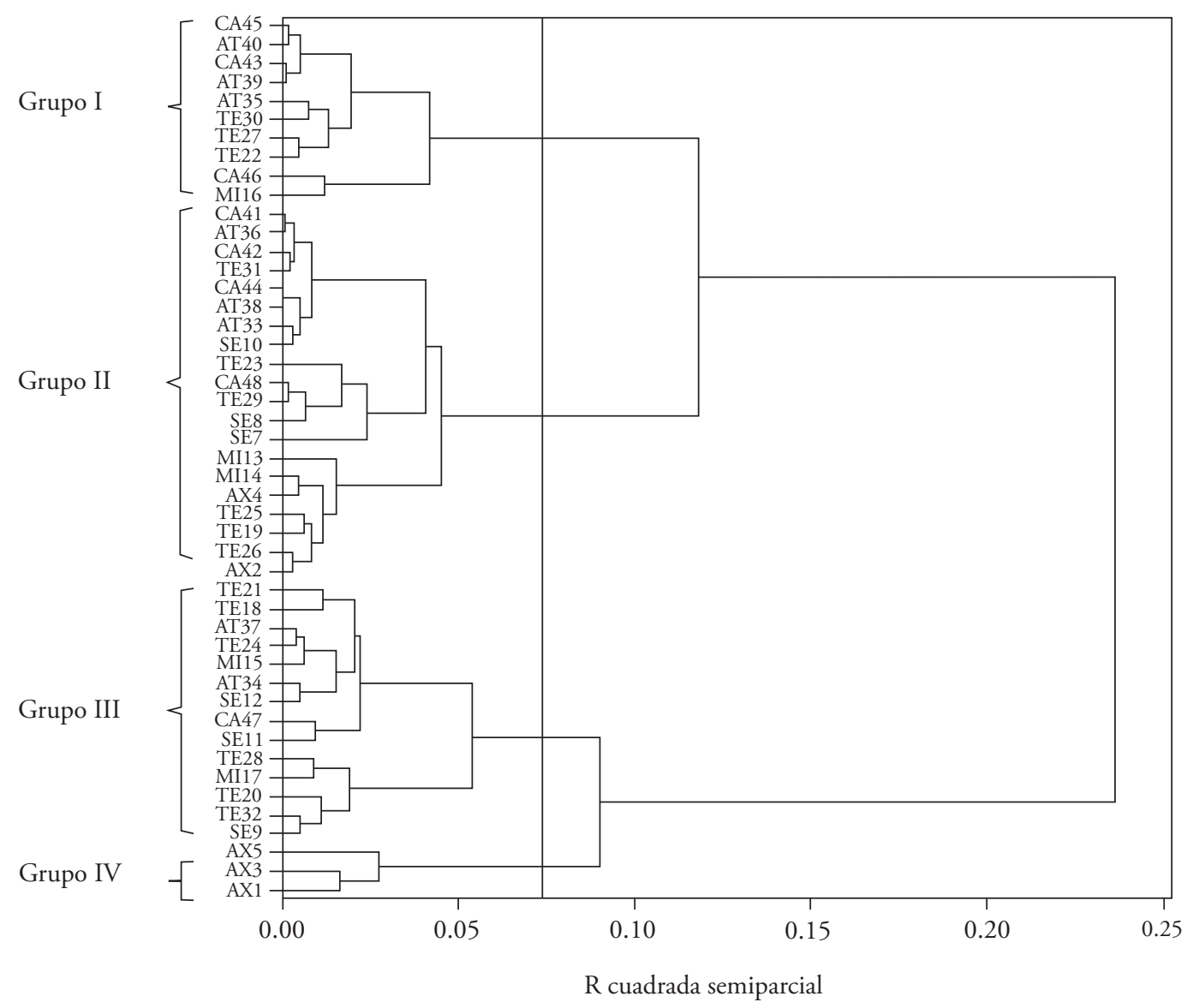

AT: Atzala, CA: Calpan, TE: Tepatlaxco de Hidalgo, SE: San Francisco Cuautlancingo, AX: Altepexi, MI: San José Miahuatlán. Los números indican el número de productor. AT: Atzala, CA: Calpan, TE: Tepatlaxco de Hidalgo, SE: San Francisco Cuautlancingo, AX: Altepexi, MI: San José Miahuatlán. The numbers following the letters indicate the number of producer.

Figura 3. Dendrograma obtenido con el método de Ward, utilizando variables de las encuestas aplicadas a productores de maíz que aprovechan el totomoxtle en seis localidades del estado de Puebla, México, 2011.

Figure 3. Dendrogram obtained with the Ward method, using variables from the surveys applied to maize producers who use totomoxtle in six localities of the state of Puebla, Mexico, 2011.

totomoxtle, escasa ganancia por su aprovechamiento y beneficio total más bajo. En contraste, los productores del grupo IV se caracterizaron por tener los más altos costos de producción por hectárea, los mejores promedios en producción de maíz en 2011, la mayor producción total de totomoxtle (rollos) y la ganancia más alta por la venta conjunta de grano y totomoxtle. Ello se debe a que se trata de productores de Altepexi, de la región de Tehuacán, donde se recurre al riego de auxilio en el ciclo del cultivo del maíz, situación que se refleja en mayores costos de producción, pero también en un mayor potencial productivo y ganancias totales, asociadas también a la mayor superficie destinada al cultivo del maíz. Los productores incluidos sale, low profit from grain sale, low production of totomoxtle rolls, scarce profit from its exploitation and lowest total benefit. In contrast, producers from Group IV were characterized by having the highest production costs per hectare, the best averages in maize production in 2011, the highest total totomoxtle production (rolls), and the highest profit from the joint sale of grain and totomoxtle. This is because they are producers from Altepexi, from the Tehuacán region, where they resort to auxiliary irrigation in the maize cultivation cycle, situation that is reflected in higher production costs, although also in a higher productive potential and total profits, also associated to the greater surface destined to 
Cuadro 3. Promedios por variable significativa para los cuatro grupos definidos en el dendrograma de productores evaluados en las tres regiones de estudio. Puebla, México, 2011.

Table 3. Averages per significant variable for the four groups defined in the dendrogram of producers evaluated in the three study regions. Puebla, Mexico, 2011.

\begin{tabular}{ccccccccc}
\hline $\mathrm{G}$ & $\mathrm{N}$ & EDAD & TIEMPO & SUP & PRODGR & VENTA & AUTOC & USEM \\
\hline 1 & 10 & $9.0 \mathrm{a}^{\dagger}$ & $49.0 \mathrm{a}$ & $2.1 \mathrm{c}$ & $1.5 \mathrm{~b}$ & $1.6 \mathrm{~b}$ & $1.5 \mathrm{~b}$ & $36.5 \mathrm{a}$ \\
2 & 20 & $46.1 \mathrm{~b}$ & & & & & & \\
3 & 14 & $57.2 \mathrm{ab}$ & $27.0 \mathrm{~b}$ & $3.1 \mathrm{bc}$ & $1.7 \mathrm{~b}$ & $2.9 \mathrm{~b}$ & $1.7 \mathrm{ab}$ & $40.5 \mathrm{a}$ \\
4 & 3 & $56.0 \mathrm{ab}$ & & & & & & \\
& & & $41.0 \mathrm{a}$ & $4.9 \mathrm{a}$ & $2.0 \mathrm{~b}$ & $6.2 \mathrm{a}$ & $2.0 \mathrm{ab}$ & $31.5 \mathrm{a}$ \\
& & $41.0 \mathrm{a}$ & $4.0 \mathrm{ab}$ & $3.0 \mathrm{a}$ & $7.0 \mathrm{a}$ & $2.3 \mathrm{a}$ & $40.1 \mathrm{a}$ \\
\hline $\mathrm{G}$ & $\mathrm{N}$ & CANI & CPROD & GANGRAN & PROTOTOT & INGTOT & ACTOT & BENTOTAL \\
\hline 1 & 10 & $0.20 \mathrm{~b}$ & $0.7 \mathrm{~b}$ & $1.0 \mathrm{~b}$ & $0.7 \mathrm{~b}$ & $2.2 \mathrm{~b}$ & $48.5 \mathrm{a}$ & $1.2 \mathrm{c}$ \\
2 & 20 & $0.05 \mathrm{~b}$ & $8.9 \mathrm{ab}$ & $3.9 \mathrm{~b}$ & $1.4 \mathrm{~b}$ & $4.1 \mathrm{~b}$ & $22.9 \mathrm{~b}$ & $8.0 \mathrm{c}$ \\
3 & 14 & $0.32 \mathrm{~b}$ & $8.9 \mathrm{ab}$ & $20.7 \mathrm{a}$ & $2.3 \mathrm{~b}$ & $7.7 \mathrm{~b}$ & $35.5 \mathrm{ab}$ & $28.4 \mathrm{~b}$ \\
4 & 3 & $1.67 \mathrm{a}$ & $12.7 \mathrm{a}$ & $22.3 \mathrm{a}$ & $12.3 \mathrm{a}$ & $18.4 \mathrm{a}$ & $41.7 \mathrm{a}$ & $40.7 \mathrm{a}$ \\
\hline
\end{tabular}

G: Grupo, N: Número de productores, EDAD: Edad del productor (años), TIEMPO: Tiempo del productor sembrando maíz (años), SUP: Superficie sembrada con maíz en 2011 (ha), PRODGR: Producción de grano en 2011 ( $\left.\mathrm{ha}^{-1}\right)$, VENTA: Venta de maíz como grano $(\mathrm{t})$, AUTOC: Grano para autoconsumo ( $\mathrm{t}$ ), USEM: Uso de maíz como semilla (k), CANI: Consumo animal (t), CPROD: Costo de producción en 2011 (\$), GANGRAN: Ganancia por la venta de grano (miles de \$), PROTOT: Producción total de totomoxtle (rollos), INGTOT: Ganancia por la venta de totomoxtle (miles de \$), ACTOT: Ańos comercializando totomoxtle, BENTOTAL: Beneficio por la venta de grano y totomoxtle (miles de \$). G: Group, N: Number of producers, EDAD: Age of the producer (years), TIEMPO: Time of the producer sowing maize (years), SUP: Surface sown with maize in 2011 (ha), PRODGR: Grain production in 2011 ( $\left(\right.$ ha $\left.^{-1}\right)$, VENTA: Maize sale as grain ( $\mathrm{t}$, AUTOC: Grain for auto-consumption ( $\mathrm{t}$ ), USEM: Use of maize as seed (k), CANI=Animal consumption ( $\mathrm{t}$ ), CPROD: Production cost in 2011 (\$), GANGRAN: Profit from grain sale (thousands of \$), PROTOT: Total totomoxtle production (rolls), INGTOT: Profit from the sale of totomoxtle (thousands of \$), ACTOT: Years selling totomoxtle, BENTOTAL: Benefit from the sale of grain and totomoxtle (thousands of \$). [Initials based on Spanish terms].

${ }^{\dagger}$ Medias con la misma letra en columnas son estadísticamente iguales (Tukey al 0.05 de probabilidad). $*{ }^{\dagger}$ Means with the same letter in columns are statistically equal (Tukey at 0.05 of probability).

en los Grupos II y III tienen similitud tanto en edad como en ańos comercializando totomoxtle, pero además tienen coincidencia en la cantidad de grano destinada al autoconsumo y al consumo animal, en los costos de producción de maíz por hectárea, en la producción total de totomoxtle y en los ingresos totales generados por su venta. En cuando a la cantidad de maíz utilizado como semilla, no hubo diferencia entre los cuatro grupos, lo que indica que los productores entrevistados seleccionan semilla del ciclo anterior para futuras siembras y esto, como lo señala King (2007), puede contribuir a la conservación del maíz como recurso fitogenético.

En general, los productores se agruparon en función de las variables detectadas como relevantes en el análisis de componentes principales. Los resultados indican que los productores con más altos rendimientos de grano, mayor producción de totomoxtle, mayores volúmenes de venta y menor porcentaje de su producción destinada al autoconsumo fueron, como era de esperarse, quienes obtuvieron las mayores ganancias. maize cultivation. The producers included in Groups II and III are similar both in age and in years selling totomoxtle and they also agree in the amount of grain destined to self-consumption and animal consumption, in the costs of maize production per hectare, in the total production of totomoxtle, and in the total income generated by its sale. When it comes to the amount of maize used as seed, there was no difference between the four groups, which indicates that the producers interviewed select seed from the previous cycle for future sowing and this, as King (2007) points out, can contribute to maize conservation as a plant genetic resource.

In general, the producers are grouped in function of the variables detected as relevant in the principal components analysis. The results indicate that the producers with highest grain yields, highest totomoxtle production, highest sale volumes, and lowest percentage of production destined to autoconsumption were, as was expected, the ones who obtained the highest profits. 
Con el análisis de correspondencias se obtuvo la Figura 4. En ella se observa la relación existente entre los agricultores de cada localidad y las variables para ellos registradas, destacando que nueve de las 20 variables utilizadas en el análisis fueron las que más contribuyeron en la asociación de productores. En el cuadrante I se muestra que productores de Altepexi se relacionaron más por la producción total de
Figure 4 was obtained with the correspondence analysis. It shows the existing relationship between farmers from each locality and the variables recorded for them, highlighting that nine out of the 20 variables used in the analysis were the ones that contributed most in the producers' association. Quadrant I shows that producers from Altepexi are related mostly with total totomoxtle production

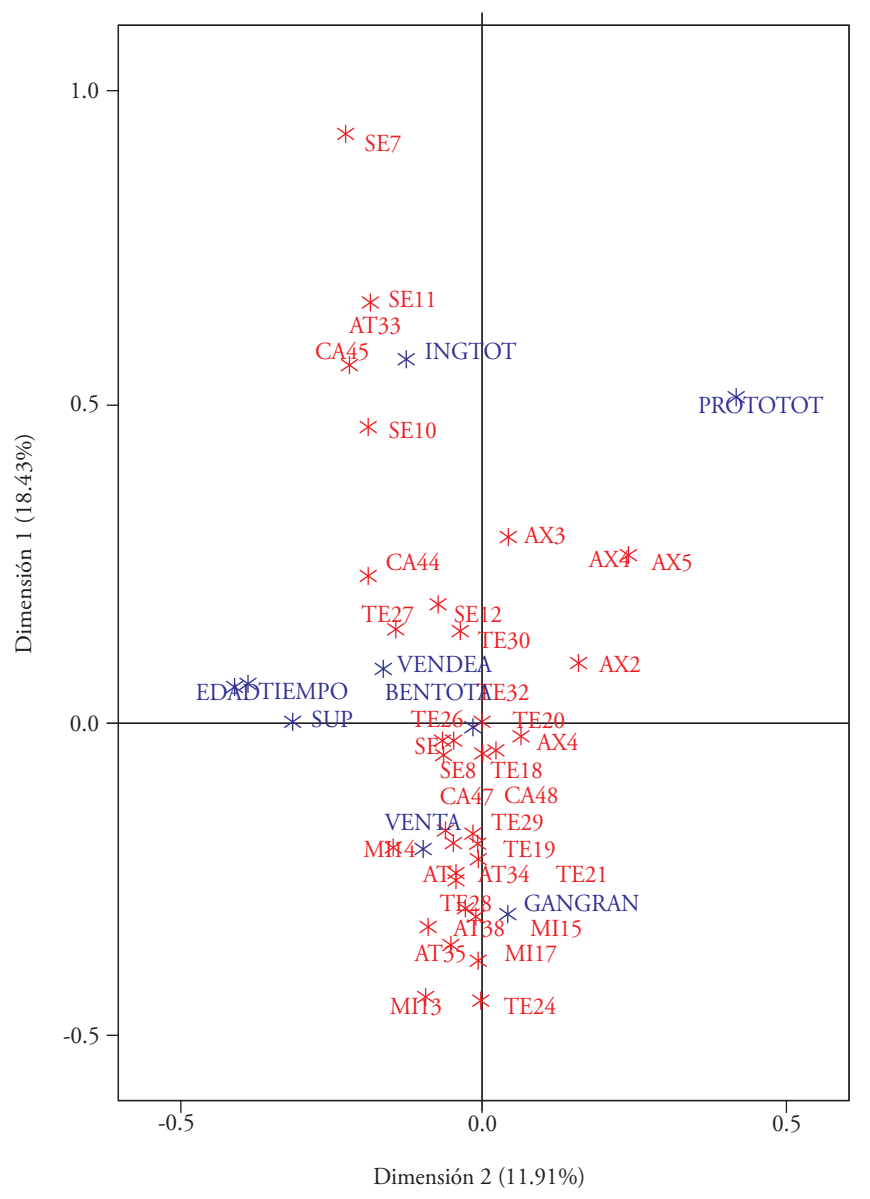

AT: Atzala, CA: Calpan, TE: Tepatlaxco de Hidalgo, SE: San Francisco Cuautlancingo, AX: Altepexi, MI: San José Miahuatlán. El número acompañante identifica al productor. EDAD: Edad del productor (años), TIEMPO: Tiempo del productor sembrando maíz (años), SUP: Superficie sembrada con maíz en 2011 (ha), VENTA: Venta de maíz como grano (t), GANGRAN: Ganancia por la venta de grano (\$), PROTOTOT: Producción total de totomoxtle (rollos), INGTOT: Ganancia por la venta de totomoxtle (\$), VENDEA: A quién vende el totomoxtle, BENTOTAL: Beneficio por la venta de grano y totomoxtle (\$). AT: Atzala, CA: Calpan, TE: Tepatlaxco de Hidalgo, SE: San Francisco Cuautlancingo, AX: Altepexi, MI: San José Miahuatlán. The accompanying number identifies the producer. EDAD: Age of the producer (years), TIEMPO: Time of the producer sowing maize (years), SUP=Surface sown with maize in 2011 (ha), VENTA: Sale of maize as grain ( $\mathrm{t}$ ), GANGRAN: Profit from grain sale (\$), PROTOTOT: Total totomoxtle production (rollos), INGTOT: Profit from totomoxtle sale (\$), VENDEA: To whom totomoxtle is sold, BENTOTAL: Benefit from the sale of grain and totomoxtle (\$). [Initials based on Spanish terms].

Figura 4. Análisis de correspondencias utilizando 20 variables de los cuestionarios aplicados a productores de maíz en seis localidades de tres regiones del estado de Puebla, México, 2011.

Figure 4. Correspondence analysis using 20 variables from the questionnaires applied to maize producers in six localities from three regions of the state of Puebla, Mexico, 2011 
totomoxtle (PROTOTOT). El cuadrante II muestra a otro grupo de productores relacionados con el ingreso total obtenido por la venta de totomoxtle (INGTOTAL). Finalmente, un grupo heterogéneo de productores, que se muestran en los cuadrantes III y IV, se asoció tanto con el volumen de grano vendido (VENTA) como con la ganancia obtenida por dicha venta (GANGRAN). En resumen, este análisis reveló que los productores se agruparon de acuerdo a la similitud que presentaron en relación a diferentes características. Ello confirma lo detectado en secciones previas: los productores de Altepexi son los que tienen una mayor producción de rollos de totomoxtle, lo cual coincide con lo reportado por Flores-Rosales et al. (2015), en el sentido de que de las regiones evaluadas, es la de Tehuacán la que tiene el mayor potencial para la producción de totomoxtle. Destaca asimismo que el ingreso total por la venta de totomoxtle diferencia a los agricultores de las regiones de Puebla y Serdán de los de Tehuacán. Las variables 'VENTA' y 'GANGRAN' (asociadas a la producción de grano) no permiten diferenciar tan claramente entre sí a los productores de totomoxtle de las tres regiones.

\section{CONCLUSIONES}

El mayor porcentaje del totomoxtle que en 2011 se comercializó en los principales mercados del estado de Puebla provino de localidades relativamente cercanas a cada mercado, destacando entre ellas Atzala, Tepatlaxco de Hidalgo, San José Miahuatlán y San Francisco Cuautlancingo.

De los productores entrevistados que comercializó totomoxtle $100 \%$ utilizó semilla de poblaciones nativas de maíz seleccionada del ciclo anterior.

Hubo diferencias entre productores comercializadores de totomoxtle atribuibles a tres conjuntos de variables: las económicas (vinculadas a la ganancia derivada de la venta de productos del maíz), las productivas, y las asociadas con el tiempo dedicado a la producción y aprovechamiento del totomoxtle.

La mayoría de los productores (59.6\%) de las tres regiones de estudio obtuvo una relación beneficiocosto menor a uno cuándo sólo se aprovechó el grano del maíz; el beneficio se incrementó entre 8.3 y $31.2 \%$ al agregar el aprovechamiento del totomoxtle.

Productores de Altepexi, de la región Tehuacán, obtuvieron los mayores volúmenes de grano y totomoxtle,
(PROTOTOT). Quadrant II shows another group of producers related with the total income obtained from the totomoxtle sale (INGTOTAL). Finally, a heterogeneous group of producers, which is shown in Quadrants III and IV, is associated both with the volume of grain sold (VENTA) and with the profit obtained from that sale (GANGRAN). In summary, this analysis revealed that the producers were grouped according to the similarity that they presented in relation to different characteristics. This confirms what was detected in previous sections: producers from Altepexi are the ones that have higher production of totomoxtle rolls, which agrees with what was reported by Flores-Rosales et al. (2015), in the sense that from the regions evaluated, it is the Tehuacán region which has the highest potential for totomoxlte production. Something that also stands out is that the total income from the sale of totomoxtle differentiates farmers from the regions of Puebla and Serdán from those from Tehuacán. The variables 'VENTA' and 'GANGRAN' (associated to grain production) do not allow differentiating the totomoxtle producers from the three regions so clearly between each other.

\section{CONCLUSIONS}

The higher percentage of totomoxtle that was sold in 2011 in the main markets of the state of Puebla came from localities that are relatively close to each market, with the following standing out among them: Atzala, Tepatlaxco de Hidalgo, San José Miahuatlán and San Francisco Cuautlancingo.

Of the producers interviewed who sold totomoxtle, $100 \%$ used seeds from native maize populations selected from the previous cycle.

There were differences between totomoxtle sellers attributable to three sets of variables: the economic (linked to the profit derived from the sale of maize products), the productive, and those associated with the time devoted to production and use of totomoxtle.

Most of the producers (59.6\%) from the three regions of study obtained a benefit-cost relation of less than one when only the maize grain was used; the benefit increased between 8.3 and $31.2 \%$ when adding the use of totomoxtle.

Producers from Altepexi, in the Tehuacán region, obtained the highest volumes of grain and 
así como los más altos beneficios por la venta de ambos productos.

De los productores, $11 \%$ consideró que la producción de totomoxtle es más relevante que la producción de grano, mientras que $76 \%$ de ellos confirió la misma importancia a la producción de grano y de totomoxtle.

\section{LITERATURA CITADA}

Andrés-Meza, P., M. Sierra-Macías, A. Espinosa-Calderón, N.O. Gómez-Montiel, A. Palafox-Caballero, F.A. RodríguezMontalvo, y M. Tadeo-Robledo. 2014. Hoja de maíz (Zea mays L.), importante actividad en la zona norte del estado de Veracruz, México. Agroproductividad 7: 32-37.

http://revista-agroproductividad.org/index.php/agroproductividad/issue/view/20

Bellon, Mauricio R., and J. Edward Taylor. 1993. "Folk" Soil Taxonomy and the Partial Adoption of New Seed Varieties. Economic Development and Cultural Change 41: 763-786. https://www.jstor.org/stable/1154273

Chun-Ying, Li, Kim Hee-Woong, Won Se-Ra, Min Hwang-Kee, Park Ki-Jin, Park Jong-Yeol, Ahn Mun-Seob, and Rhee HaeIk. 2008. Corn husk as a source of anthocyanins. Journal of Agricultural and Food Chemistry 56: 11413-11416.

Cruz-Meza, Pedro, Eugenio Romantchick-Kriuchkova, y Federico Hahn. 2010. Diseño, construcción y evaluación de una máquina para deshojar la mazorca de maíz para envoltura de tamal. Ingeniería Agrícola y Biosistemas 2: 69-74. http://dx.doi.org/10.5154/r.inagbi.2010.10.018

Demissie, Girma, Tadele Tefera, and Abraham Tadesse. 2008. Importance of Husk Covering on Field Infestation of Maize by Sitophilus zaemais Motsch (Coleoptera: Curcolionidea) at Bako, Western Ethiopia. African Journal of Biotechnology 7: 3777-3782. http://www.academicjournals.org/article/article1379780263_Demissie\%20et\%20al.pdf

Dong, Jianwei, Le Cai, Xiufang Zhu, Xing Huang, Tianpeng Yin, Haixian Fang, and Zhongtao Ding. 2014. Antioxidant Activities and Phenolic Compounds of Cornhusk, Corncob and Stigma Maydis. J. Braz. Chem. Soc. 25: 1956-1964. http://dx.doi.org/10.5935/0103-5053.20140177

Eakin, Hallie, Hugo Perales, Kirsten Appendini, and Stuart Sweeney. 2014.Selling Maize in Mexico: The Persistence of Peasant Farming in an Era of Global Markets. Development and Change 45: 133-155. http://onlinelibrary.wiley.com/ doi/10.1111/dech.12074/epdf

Flores-Rosales, Martha del Carmen, J. Arahón HernándezGuzmán, Abel Gil-Muñoz, Pedro Antonio López, Filemón Parra-Inzunza, y Felix Valerio González-Cossío. 2015. Variability in cornhusk traits of landraces from the State of Puebla, Mexico. Agronomy Journal 107: 1119-1127. https:// dl.sciencesocieties.org/publications/aj/pdfs/107/3/1119

Hellin, Jon, Alder Keleman, and Muricio Bellon. 2010. Maize Diversity and Gender: Research from Mexico. Gender and Development 18: 427-437. https://policy-practice.oxfam. org.uk/publications/maize-diversity-and-gender-researchfrom-mexico-131744

Hellin, Jon, Alder Keleman, Damaris López, Laura Donnet, y totomoxtle, as well as the highest benefits from the sale of both products.

Of the producers, $11 \%$ considered that totomoxtle production is more relevant than grain production, while $76 \%$ of them gave the same importance to production of grain and of totomoxtle.

- End of the English version-

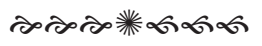

Dagoberto Flores. 2013. La importancia de los nichos de mercado: un estudio de caso del maíz azul y del maíz para pozole en México. Revista Fitotecnia Mexicana 36 (Supl. 3-A): 315-328. https://www.revistafitotecniamexicana.org/ documentos/36-supl-3-A/5a.pdf

Hernández-Guzmán, J. Arahón, y Filemón Parra Inzunza. 2007. Valor agregado en la producción de maíz; el caso de la industria del totomoxtle en Jala, Nayarit. En: II Foro Internacional Biológico Agropecuario. Celebrado en Tuxpan, Veracruz, del 24 al 27 de Septiembre de 2007. Universidad Veracruzana, Facultad de Ciencias Biológicas y Agropecuarias. Tuxpan, Ver., México. Pp: 156-164.

Jain, Archana, Deepali Rastogi, Bhawana Chanana, M.S.Parmar, and Aditi Dhama. 2017. Extraction of cornhusk fibres for textile usages. IOSR Journal of Polymer and Textile Engineering (IOSR-JPTE) 4: 29-34. DOI: $10.9790 / 019 X-04012934$.

Kang, M.S., M.S. Zuber, T.R. Colbert, and R.D. Horrocks. 1986. Effects of Certain Agronomic Traits on and Relationship between Rates of Grain-Moisture Reduction and Grain Fill during the Filling Period in Maize. Field Crops Research 14:339-347. https://ac.els-cdn.com/0378429086900687/1s2.0-0378429086900687-main.pdf?_tid=43249768-012b11e8-8922-00000aab0f6b\&acdnat $=1516814784 \_589 \mathrm{fab} 0$ $0083 \mathrm{a} 67315$ ccc5eba781f3660

Keleman, Alder, and Jon Hellin. 2009. Specialty Maize Varieties in Mexico: A Case Study in market-Driven Agro-Biodiversity Conservation. Journal of Latin American Geography 8: 147-174. https://muse.jhu.edu/article/315981

Keleman, Alder, Jon Hellin, and Mauricio Bellon. 2009. Maize Diversity, Rural Development Policy, and Farmers' Practices: Lessons from Chiapas, Mexico. The Geographical Journal 175: 52-70. https://www.jstor.org/stable/pdf/40205267.pd f?refreqid=excelsior\%3A17fc64345183854e160f72a0d16b 8 ec5

Keleman, Alder, Jon Hellin, and Dagoberto Flores. 2013. Diverse Varieties and Diverse Markets: Scale-related Maize "Profitability Crossover" in the Central Mexican Highlands. Human Ecology 41: 683-705. https://link.springer.com/ content/pdf/10.1007\%2Fs10745-013-9566-z.pdf

King, Amanda. 2007. Trade and Totomoxtle: Livelihood Strategies in the Totonacan Region of Veracruz, México. Agriculture and Human Values 24: 29-40. https://link.springer. com/content/pdf/10.1007\%2Fs10460-006-9031-3.pdf

Lihua, LV, Jihong Bi, Fang Ye, Yongfang Qian,Yuping Zhao, Ru Chen, and Xinggen Su. 2017. Extraction of discarded corn 
husk fibers and its flame retarded composites. Tekstil ve Konfeksiyon 27: 408-413. http://dergipark.gov.tr/download/ article-file/393379ipark.gov.tr/download/article-f

Long, Norman, and Magdalena Villarreal. 1998. Small Product, Big Issues: Value Contestations and Cultural Identities in Cross-Border Commodity Networks. Development and Change 29: 725-750. http://onlinelibrary.wiley.com/ doi/10.1111/1467-7660.00097/epdf

Mohammadi, S.A., and B.M. Prasanna. 2003. Analysis of Genetic Diversity in Crop Plants-Salient Statistical Tools and Considerations. Crop Science 43: 1235-1248. https:// dl.sciencesocieties.org/publications/cs/pdfs/43/4/1235

Muñoz, Orozco Abel. 2005. Centli-Maíz: prehistoria e historia, diversidad, potencial, origen genético y geográfico, glosario Centli-Maíz. Colegio de Postgraduados, Texcoco, Edo de México, 210 p.

Ortiz-Torres, Enrique, Pedro Antonio López, Abel Gil-Muñoz, Juan de Dios Guerrero-Rodríguez, Higinio López-Sánchez, Oswaldo R. Taboada-Gaytán, J. Arahón Hernández-Guzmán, y Mario Valadez-Ramírez. 2013. Rendimiento y calidad de elote en poblaciones nativas de maíz de Tehuacán, Puebla. Revista Chapingo Serie Horticultura 19: 225-238. http://www.scielo.org.mx/pdf/rcsh/v19n2/v19n2a8.pdf

Pengelly, Jasper J.L., Scott Kwasny, Soumi Bala, John R. Evans, Elena V. Voznesenskaya, Nuria K. Koteyeva, Gerald E. Edwards, Robert T. Furbank, and Susanne von Caemmerer. 2011. Functional analysis of corn husk photosynthesis. Plant Physiology 156: 503-513. www.plantphysiol.org/cgi/ doi/10.1104/pp.111.176495

Reddy, Narendra, and Yiqi Yang. 2005a. Properties and Potential Applications of Natural Cellulose Fibers from Cornhusks. Green Chemistry 7: 190-195. http://pubs.rsc.org/en/Content/ArticleLanding/2005/GC/b415102j\#!divAbstract

Reddy, Narendra, and Yiqi Yang. 2005b. Biofibers from Agri- cultural Byproducts for Industrial Applications. Trends in Biotechnology 23: 22-27. https://ac.els-cdn.com/ S0167779904003191/1-s2.0-S0167779904003191main.pdf?_tid=1c 2 e 2 e 7 c- 012 f- 11 e 8 - 9714 00000aab0f27\&acdnat $=1516816428 \_e 905 \mathrm{df} 18 \mathrm{e} 627 \mathrm{~d}$ 778c4e7973a7da6ce0a

Rice, Elizabeth. 2007. Conservation in a Changing World: in situ Conservation of the Giant Maize of Jala. Genetic Resources and Crop Evolution 54: 701-713. https://link.springer.com/content/pdf/10.1007\%2Fs10722-006-0023-3.pdf

SAS (Statistical Analysis System). 2008. SAS User's Guide: Statistics. Versión 8.0. SAS Institute Inc., Cary, N.C, USA.

SIAP (Servicio de Información Estadística Agroalimentaria y Pesquera). 2016. Anuario Estadístico de la Producción Agrícola. México, D.F. Consultado el 17 de enero de 2018 en: www.siap.gob.mx_siap/icultivo/index.jsp.

Sweeney, Stuart, Douglas G. Steigerwald, Frank Davenport, and Hallie Eakin. 2013. Mexican Maize Production: Evolving Organizational and Spatial Structures since 1980. Applied Geography 39: 78-92. https://ac.els-cdn.com/S0143622812001701/1-s2.0S0143622812001701-main.pdf?_tid=ff463690-0130-11e89813-00000aacb362\&acdnat $=1516817239 \_d 1562$ af3e114167cdd965abb09e09fe2

Toledo, Víctor Manual, Julia Carabias, Cristina Mapes, y Carlos Toledo. 2006. Ecología y Autosuficiencia Alimentaria. Siglo XXI Editores. México. 118 p.

Viveros, Flores Cresencia Emma, Abel Gil Muñoz, Pedro Antonio López, Benito Ramírez Valverde, Juan de Dios Guerrero Rodríguez, and Artemio Cruz-León. 2010. Patrones de utilización del maíz en unidades de producción familiar del valle de Puebla, México. Tropical and Subtropical Agroecosystems 12: 471-484. http://www.redalyc.org/ pdf/939/93915170008.pdf 